\title{
CAKUPAN PEMBERIAN ASI EKSKLUSIF: AKURASI DAN INTERPRETASI DATA SURVEI DAN LAPORAN PROGRAM
}

\author{
Yekti Widodo ${ }^{1}$ \\ ${ }^{1}$ Puslitbang Gizi dan Makanan Bogor
}

\begin{abstract}
ABSTRAK
Akurasi dan interpretasi cakupan data pemberian air susu ibu (ASI) eksklusif atau menyusui eksklusif sangat penting diketahui untuk memberikan gambaran tentang status menyusui eksklusif di suatu negara. Di Indonesia data cakupan praktik menyusui eksklusif pada bayi di bawah usia 6 bulan berbeda-beda tergantung pada definisi dan metode pengumpulan data yang digunakan. Cakupan praktik menyusui eksklusif pada bayi di bawah usia 6 bulan berkisar antara 15,3 sampai 74,2 persen. Akurasi dan interpretasi data cakupan tersebut sangat penting untuk diketahui. Data cakupan tersebut menjadi berbahaya karena dapat menyebabkan kesalahan interpretasi dan menimbulkan asumsi bahwa cakupan praktik menyusui eksklusif di Indonesia sudah mencapai angka yang tinggi, dan jika hal tersebut diyakini oleh para petugas kesehatan maka upaya untuk meningkatkan cakupan praktik menyusui eksklusif akan semakin melemah. Hal ini menjadi sangat berbahaya terhadap upaya meningkatkan cakupan praktik menyusui eksklusif. Perbedaan interpretasi data survei dan definisi tentang menyusui eksklusif perlu dibahas berdasarkan sumber pustaka yang relevan. Rekomendasi berdasarkan interpretasi data cakupan praktik menyusui eksklusif hanya dapat dilakukan setelah dievaluasi secara hati-hati dan cermat terhadap definisi dan metode survey yang digunakan,
\end{abstract}

Kata kunci: ASI ekslusif, akurasi, interpretasi

\section{ABSTRACT}

\section{EXCLUSIVE BREASTFEEDING: ACCURACY AND INTERPRETATION DATA SURVEY AND PROGRAM REPORTED}

Accuracy and interpretation of reported of exclusive breastfeeding (EBF) rates is essential in order to understand the true picture of exclusive breastfeeding status in one country. In Indonesia, it was reported that exclusive breastfeeding rate among infants aged under six months is varied depending on its definition and data collection methods. Data of exclusive breastfed rates among infants aged under six months ranged from $15,3 \%$ to $74,2 \%$. Accuracy and interpretation of these rates are important for the health program development. The danger of misinterpreting these data and false assuming that Indonesia has achieved a high exclusive breastfeeding rate by health workers lead to accept the believe that no further effort should be made in this area. This will be a potential problem for further improvement of practicing exclusively breastfeeding in fields. The difference of data survey and interpretation of various definitions of EBF should be based on the relevant literatures. It is strongly recommended that interpretation of exclusive breastfeeding rates should be carefully evaluated on the basis of its definitions and survey methods used.

Keywords: exclusive breastfeeding, accuracy, interpretation

\section{PENDAHULUAN}

raktik pemberian Air Susu Ibu (ASI) atau menyusui bayi dilakukan di berbagai lapisan masyarakat di seluruh dunia, karena banyak manfaat yang diperoleh dari ASI dan praktik menyusui. ${ }^{1}$ Pada kondisi yang kurang menguntungkan seperti di negaranegara berkembang, di mana masyarakat mempunyai keterbatasan ekonomi dan higiene, menyusui atau pemberian ASI merupakan cara pemberian makanan yang sangat tepat dan kesempatan terbaik bagi kelangsungan hidup bayi ${ }^{2}$, serta dapat mempertemukan kebutuhan ibu dan anak. ${ }^{3}$

Pemberian makanan yang tepat dan optimal sangat penting untuk kelangsungan hidup, pertumbuhan dan perkembangan bayi dan anak usia bawah dua tahun (baduta). Menurut Global Strategy on Infant and Young Child Feeding, pemberian makanan yang tepat adalah menyusui bayi sesegera mungkin setelah lahir, memberikan ASI eksklusif sampai umur 6 bulan, memberikan makanan pendamping ASI yang tepat dan adekuat sejak 
usia 6 bulan, dan melanjutkan pemberian ASI sampai umur 2 tahun atau lebih. ${ }^{4}$

Pemberian ASI eksklusif atau menyusui eksklusif sampai bayi umur 6 bulan sangat menguntungkan karena dapat melindungi bayi dari berbagai penyakit penyebab kematian bayi. ${ }^{5,6}$ Selain menguntungkan bayi, pemberian ASI eksklusif juga menguntungkan ibu, yaitu mengurangi perdarahan pasca persalinan ${ }^{7,8}$, mengurangi kehilangan darah pada saat haid ${ }^{9}$, mempercepat pencapaian berat badan sebelum hamil ${ }^{10}$, mengurangi risiko kanker payudara ${ }^{11}$ dan kanker rahim. ${ }^{12}$ Meskipun menyusui dan ASI sangat bermanfaat, diperkirakan 85 persen ibu-ibu di dunia tidak memberikan ASI secara optimal. Hal ini tampak bahwa pemberian ASI eksklusif seperti yang direkomendasikan oleh WHO (2002) ${ }^{4}$ masih jarang dipraktikan oleh ibuibu di berbagai negara, karena berbagai faktor, seperti sosial, budaya, ekonomi, dan politik. ${ }^{8}$

\section{Istilah Pemberian ASI atau Menyusui}

Definisi pemberian ASI atau menyusui menurut WHO (2002) ${ }^{4}$ adalah sebagai berikut:

1. Pemberian ASI eksklusif atau menyusui eksklusif adalah memberikan hanya ASI pada bayi dan tidak memberi bayi makanan atau minuman lain, termasuk air putih, kecuali obat-obatan dan vitamin atau mineral tetes; ASI perah juga diperbolehkan, yang dilakukan sampai bayi berumur 6 bulan.

2. Pemberian ASI eksklusif atau menyusui predominan adalah menyusui bayi, tetapi pernah memberikan sedikit air atau minuman berbasis air, misalnya teh (biasanya sebagai makanan/minuman prelakteal sebelum ASI keluar).

3. Pemberian ASI eksklusif atau menyusui parsial adalah menyusui bayi serta memberikan makanan buatan selain ASI, baik susu formula, bubur atau makanan lainnya, (baik diberikan secara kontinyu maupun diberikan sebagai makanan prelakteal).

\section{METODE PENGUMPULAN DATA PEMBERIAN ASI EKSKLUSIF}

Metode pengumpulan data pemberian ASI eksklusif masih menjadi perdebatan dan belum ada satu metode yang disepakati. Pada survei atau penelitian cross-sectional WHO (2002) ${ }^{4}$ merekomendasikan, pengumpulan data pemberian AS eksklusif dilakukan dengan metode recall 24 jam. Rentang waktu yang disyaratkan dalam metode recall 24 jam adalah satu hari sebelum survei. Sebagian ahli menganggap bahwa metode recall 24 jam mempunyai keterbatasan, yaitu periode recall yang terlalu singkat, padahal WHO (2002) ${ }^{4}$ menekankan pemberian ASI sejak lahir. Data yang diperoleh melalui metode recall 24 jam selalu lebih tinggi daripada data aktual di populasi, karena bayi yang dalam 24 jam terakhir hanya diberi ASI saja dikategorikan diberi ASI eksklusif, meskipun pada hari-hari sebelumnya sudah diberi makanan selain $\mathrm{ASI}{ }^{13}$

Metode lain yang dapat digunakan untuk mengumpulkan data pemberian ASI eksklusif adalah metode recall sejak lahir. Metode recall sejak lahir membutuhkan periode recall yang lebih lama, yaitu riwayat pemberian ASI sejak bayi lahir, bukan hanya 24 jam terakhir. ${ }^{14}$ Perbedaan metode recall 24 jam dengan recall sejak lahir adalah penentuan kategori pemberian ASI eksklusif.

Kategori bayi diberi ASI eksklusif berdasarkan metode recall 24 jam adalah jika dalam 24 jam terakhir bayi tidak pernah mendapat makanan atau minuman lain selain ASI. Menurut metode recall sejak lahir, bayi dikategorikan diberi ASI eksklusif hanya jika sejak lahir bayi tidak pernah mendapat makanan atau minuman lain selain ASI.

\section{Estimasi Cakupan Pemberian ASI Eksklusif di Populasi}

Estimasi cakupan pemberian ASI eksklusif di populasi sangat tergantung pada metode yang digunakan dalam pengumpulan data. Selain itu batasan umur atau kategori umur bayi juga sangat penting dalam mengukur cakupan pemberian ASI eksklusif di populasi. WHO merekomendasikan penggunaan indikator pemberian ASI eksklusif di bawah enam bulan yang didefinisikan sebagai proporsi bayi $0-5$ bulan yang hanya diberi ASI saja dan datanya dikumpulkan dengan metode recall 24 jam. Cara penghitungan cakupan pemberian ASI eksklusif menggunakan rumus sebagai berikut: 
Rentang umur metode ini adalah dari lahir sampai di bawah umur 6 bulan (0-5,99 bulan). Perlu dicatat bahwa numerator dan denominator keduanya meliputi semua bayi dalam rentang umur tersebut. WHO juga merekomendasikan untuk mengkategorikan ke dalam kelompok umur 0-1 bulan, 2-3 bulan, dan 4-5 bulan. Pengelompokan umur hanya dapat merepresentasikan cakupan pemberian ASI eksklusif pada kelompok umur tersebut, dan tidak dapat merepresentasikan proporsi bayi yang diberi ASI eksklusif sampai umur di bawah 6 bulan (5,99 bulan).

\section{CAKUPAN PEMBERIAN ASI EKSKLUSIF DI INDONESIA}

Di Indonesia akurasi data cakupan pemberian ASI eksklusif sampai umur 6 bulan masih menjadi pertanyaan bagi para penyusun kebijakan, pengelola program, praktisi dan pemerhati masalah kesehatan. Hal tersebut terjadi karena:

1. Kesalahan interpretasi terhadap data cakupan pemberian ASI eksklusif hasil survei atau penelitian.

2. Data cakupan pemberian ASI eksklusif yang dilaporkan/dipublikasikan tidak disertai dengan penjelasan metode pengumpulan data secara terinci.

3. Laporan/publikasi hasil penelitian tidak dibaca secara menyeluruh dan ditelaah secara kritis, tetapi hanya dibaca bagian hasil atau kesimpulan.

4. Data cakupan pemberian ASI eksklusif laporan pengelola program berbeda dengan data laporan survei.
Praktik pemberian ASI atau bayi yang disusui di Indonesia cenderung menurun. Data Survei Demografi dan Kesehatan Indonesia (SDKI) tahun 2007 menunjukkan bahwa bayi dan anak usia bawah lima tahun (balita) yang pernah disusui adalah 95,2 persen ${ }^{15}$, sedangkan data Riset Kesehatan Dasar (Riskesdas) tahun 2010 bayi dan anak baduta yang pernah disusui hanya 90,3 persen. ${ }^{16}$

Riskesdas 2010 menunjukkan bahwa praktik pemberian ASI di perdesaan relatif lebih tinggi daripada di perkotaan. Bayi dan anak baduta yang pernah diberi ASI di perdesaan 91,8 persen, sedangkan di perkotaan 88,8 persen. Praktik pemberian ASI menurut status ekonomi rumah tangga terdapat kecenderungan semakin tinggi status ekonomi rumah tangga semakin rendah praktik pemberian ASI pada bayi dan baduta. Pada kelompok status ekonomi terendah praktik pemberian ASI mencapai 92,3 persen, sedangkan pada kelompok status ekonomi tertinggi hanya 85,7 persen. ${ }^{16}$

Sumber data cakupan pemberian ASI eksklusif di Indonesia antara lain dari SDKI, laporan program dan Riskesdas 2010. Metode yang digunakan dalam pengumpulan data cakupan pemberian ASI eksklusif SDKI 2002 dan 2007 adalah metode recall 24 jam dengan batasan umur 0-5 bulan. Menurut SDKI 2002 cakupan pemberian ASI eksklusif pada bayi umur $0-5$ bulan adalah 40,0 persen dan pada tahun 2007 turun menjadi 32,0 persen. ${ }^{15,17}$ Angka tersebut adalah angka rata-rata cakupan pemberian ASI eksklusif pada bayi umur 0-5 bulan. Selain disajikan dalam angka rata-rata, data cakupan pemberian ASI eksklusif SDKI 2007 juga disajikan menurut kelompok umur.

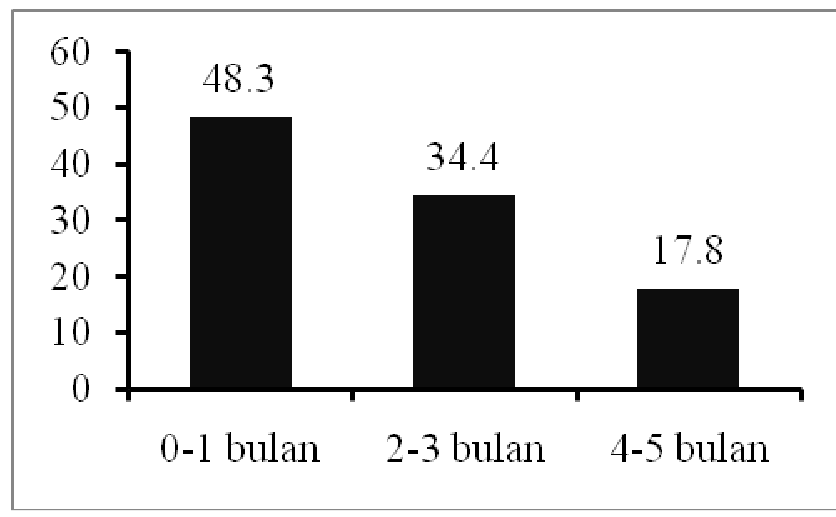

Grafik 1

Persentase Pemberian ASI Eksklusif Bayi 0-5 menurut Kelompok Umur 
Data pada Grafik 1 menunjukkan bahwa persentase cakupan pemberian ASI eksklusif menurut kelompok umur cenderung menurun dengan meningkatnya kelompok umur bayi. Cakupan tertinggi terdapat pada bayi kelompok umur 0-1 bulan dan terendah pada bayi kelompok umur 4-5 bulan. Cakupan pemberian ASI eksklusif pada kelompok umur 4-5 bulan adalah angka estimasi pemberian ASI eksklusif di populasi.

Selain data hasil survei, data cakupan pemberian ASI eksklusif sampai umur 6 bulan juga terdapat dalam laporan cakupan indikator Standar Pelayanan Minimal (SPM). Menurut laporan cakupan indikator SPM, cakupan pemberian ASI eksklusif pada bayi 0-5 bulan, sejak tahun 2003 sampai 2007, berturut-turut adalah 43,42 persen, 54,28 persen, 58,25 persen, 54,92 persen, dan 74,2 persen. ${ }^{18}$ Data yang disajikan pada tabel cakupan indikator SPM tidak dijelaskan metode pengumpulan data cakupan pemberian ASI eksklusif.

Riskesdas 2010 juga mengumpulkan data cakupan pemberian ASI eksklusif menggunakan kombinasi metode recall 24 jam dengan metode recall sejak lahir dengan batasan umur bayi 0-5 bulan. Pada Riskesdas 2010 data cakupan menyusui eksklusif diperoleh dari komposit empat pertanyaan berikut: 16

1. Apakah dalam 24 jam terakhir bayi hanya disusui/diberi ASI saja?

2. Apakah sebelum ASI keluar bayi diberi minuman (cairan) atau makanan selain ASI?

3. Sejak kapan (pada umur berapa hari/bulan) bayi mulai diberi minuman atau makanan pendamping ASI?

4. Minuman atau makanan apa saja yang diberikan kepada bayi sebelum ASI keluar?

Penyajian data cakupan pemberian ASI eksklusif Riskesdas 2010 dikategori menjadi tiga. ${ }^{16}$ Hal ini dimaksudkan untuk membantu mengatasi terjadinya perbedaan persepsi dan interpretasi diantara para penyusun kebijakan, pengelola program, praktisi dan pemerhati masalah kesehatan, serta masyarakat. Ketiga kategori tersebut adalah sebagai berikut:

1. Kategori 1: pemberian ASI eksklusif yang dikumpulkan dengan metode recall 24 jam yang digunakan SDKI 2002 dan 2007. Bayi dinyatakan diberi
ASI eksklusif jika dalam 24 jam terakhir bayi hanya disusui/diberi ASI saja.

2. Kategori 2: pemberian ASI eksklusif yang dikumpulkan dengan metode recall 24 jam dan recall sejak lahir. Bayi dinyatakan diberi ASI eksklusif jika dalam 24 jam terakhir bayi hanya disusui/diberi ASI saja dan sejak lahir sampai saat survei bayi belum diberi makanan atau minuman selain ASI.

3. Kategori 3: pemberian ASI eksklusif yang dikumpulkan dengan metode recall 24 jam dan recall sejak lahir, serta dikontrol dengan pemberian makanan prelakteal. Bayi dinyatakan diberi ASI eksklusif hanya jika dalam 24 jam terakhir bayi hanya disusui/diberi ASI saja; sejak lahir sampai saat survei bayi belum diberi makanan atau minuman selain ASl; dan sebelum ASI keluar bayi tidak diberi makanan prelakteal berupa makanan atau minuman lain, termasuk air putih, selain menyusui (kecuali obat-obatan dan vitamin atau mineral tetes; ASI perah juga diperbolehkan).

Pada Riskesdas 2010 dilakukan analisis dan penyajian data cakupan pemberian ASI eksklusif berdasarkan metode recall 24 jam saja (Kategori 1), kombinasi recall 24 jam dengan recall sejak lahir (Kategori 2) dan kombiasi recall 24 jam dengan recall sejak lahir serta dikontrol dengan pemberian makanan prelakteal (Kategori3). ${ }^{16}$ Makanan prelakteal adalah makanan atau minuman selain ASI yang pernah diberikan kepada bayi baru lahir pada saat ASI belum keluar/belum lancar atau sebelum mulai disusui. Analisis dan penyajian data tersebut, dimaksudkan untuk membandingkan data cakupan pemberian ASI eksklusif yang dikumpulkan dengan metode yang berbeda.

Hasil Riskesdas 2010 menunjukkan bahwa cakupan pemberian ASI eksklusif pada bayi umur 0-5 bulan untuk Kategori 1, 2, dan 3 berturut-turut adalah 68,9 persen, 38,4 persen dan 27,2 persen. ${ }^{16}$ Angka tersebut adalah angka rata-rata cakupan pemberian ASI eksklusif pada bayi umur 0-5 bulan. Selain disajikan dalam angka rata-rata, data cakupan pemberian ASI eksklusif Riskesdas 2010 juga disajikan menurut kelompok umur bayi. 
Tabel 1 menunjukkan bahwa pada ketiga kategori, persentase cakupan pemberian ASI eksklusif menurut kelompok umur cenderung menurun dengan meningkatnya kelompok umur bayi. Cakupan tertinggi terdapat pada bayi kelompok umur 0 bulan dan terendah pada bayi kelompok umur 5 bulan. Cakupan pemberian ASI yang dikumpulkan dengan metode recall 24 jam adalah tertinggi, namun setelah dikombinasi dengan metode recall sejak lahir, menjadi lebih rendah dan setelah dikontrol dengan pemberian makanan prelakteal menjadi lebih rendah lagi. Artinya sebagian bayi yang dalam 24 jam terakhir hanya diberi ASI saja ternyata sudah diberi makanan atau minuman selain ASI pada hari-hari sebelumnya, dan sebelum disusui atau sebelum ASI keluar sebagian bayi pernah diberi makanan prelakteal.

Tabel 1

Persentase Pemberian ASI Eksklusif menurut Kelompok Umur Bayi

\begin{tabular}{cccc}
\hline Kelompok Umur & \multicolumn{3}{c}{ Kategori Pemberian ASI Eksklusif } \\
\cline { 2 - 4 } Bayi & Kategori 1 & Kategori 2 & Kategori 3 \\
\hline 0 bulan & 82,5 & 55,9 & 39,8 \\
1 bulan & 75,1 & 46,6 & 32,5 \\
2 bulan & 74,0 & 45,6 & 30,7 \\
3 bulan & 66,9 & 35,4 & 25,2 \\
4 bulan & 66,8 & 35,4 & 26,3 \\
5 bulan & 54,8 & 22,3 & 15,3 \\
\hline
\end{tabular}

\section{INTERPRETASI DATA CAKUPAN PEMBERIAN ASI EKSKLUSIF}

Selama belum ada kesepakatan tentang batasan umur dan metode survei yang digunakan untuk mengukur cakupan pemberian ASI eksklusif, maka interpretasi data hasil survei dan laporan program sangat bergantung pada batasan umur dan metode yang digunakan. SDKI 2002 dan 2007 menggunakan batasan umur dan metode survei berdasarkan rekomendasi WHO (2002), yaitu metode recall 24 jam dengan batasan umur 0-5 bulan. Data SDKI 2002 dan 2007 menunjukkan bahwa cakupan pemberian ASI eksklusif pada bayi $0-5$ bulan adalah 40,0 persen dan 32,0 persen. ${ }^{15,17}$ Angka tersebut adalah angka rata-rata cakupan pemberian ASI eksklusif pada bayi umur 0-5 bulan, bukan persentase bayi yang diberi ASI eksklusif sampai umur 6 bulan.

Selain angka cakupan rata-rata, SDKI 2007 juga menyajikan data cakupan pemberian ASI eksklusif menurut kelompok umur. Data cakupan pemberian ASI eksklusif menurut kelompok umur adalah sebagai berikut: kelompok umur 0-1 bulan 48,3 persen, umur 2-3 bulan 34,3 persen dan umur 4-5 bulan 17,8 persen. ${ }^{17}$ Angka cakupan sebesar 17,8 persen pada kelompok umur 4-5 bulan, sebenarnya bukan angka cakupan pemberian ASI sampai umur 6 bulan, karena pada kelompok tersebut terdapat bayi yang berumur 4 bulan sampai dengan 5 bulan 29 hari.

Metode pengumpulan data cakupan pemberian ASI eksklusif yang digunakan pada SDKI 2007 adalah metode recall 24 jam. Jadi di antara 17,8 persen bayi kelompok umur 4-5 bulan yang diberi ASI eksklusif (hanya diberi ASI saja dalam 24 jam terakhir) kemungkinan terdapat bayi yang sudah diberi makanan atau minuman pada hari-hari sebelumnya. ${ }^{17}$ Secara aktual persentase pemberian ASI eksklusif di populasi lebih rendah dari hasil survei dengan metode recall 24 jam.

Riskesdas 2010 telah melakukan pengumpulan data cakupan pemberian ASI eksklusif menggunakan metode recall 24 jam dikombinasi dengan recall sejak lahir serta dikontrol dengan pemberian makanan prelakteal, dengan tujuan untuk memperoleh data estimasi cakupan pemberian ASI eksklusif yang lebih mendekati data aktual di populasi. Riskesdas 2010 menyajikan data cakupan pemberian ASI eksklusif dalam tiga kategori. ${ }^{16}$

Pemberian ASI eksklusif, kategori 3 merupakan pemberian ASI eksklusif yang paling 
sesuai dengan definisi menurut WHO. Data Riskesdas 2010 menunjukkan bahwa cakupan pemberian ASI eksklusif kategori 3 pada bayi 05 bulan adalah 27,2 persen. Angka tersebut adalah angka rata-rata cakupan pemberian ASI eksklusif pada bayi umur 0-5 bulan, bukan persentase bayi yang diberi ASI eksklusif sampai umur 6 bulan.

Estimasi untuk mengetahui cakupan bayi yang diberi ASI eksklusif sampai umur 6 bulan adalah dengan pengelompokan umur bayi. Riskesdas 2010 telah menyajikan data cakupan pemberian ASI eksklusif menurut umur bayi 0 , 1, 2, 3, 4, dan 5 bulan. Data Tabel 1 menunjukkan bahwa cakupan pemberian ASI eksklusif pada bayi kelompok umur 5 bulan adalah 15,3 persen. Angka cakupan sebesar 15,3 persen pada bayi kelompok umur 5 bulan, sebenarnya bukan angka cakupan pemberian ASI sampai umur 6 bulan, karena pada kelompok tersebut terdapat bayi yang berumur 5 bulan sampai dengan 5 bulan 29 hari. ${ }^{16}$

Cakupan pemberian ASI eksklusif pada bayi kelompok umur 5 bulan hasil Riskesdas 2010 sebenarnya merupakan angka estimasi cakupan pemberian ASI eksklusif sampai 6 bulan yang paling mendekati angka aktual di populasi. Hal ini dikarenakan metode yang digunakan untuk mengumpulkan data merupakan kombinasi metode recall 24 jam dengan recall sejak lahir dan dikontrol dengan pemberian makanan atau minuman prelakteal. Metode yang paling tepat untuk mengukur cakupan pemberian ASI eksklusif sampai umur 6 bulan adalah dengan metode kohor, yaitu melakukan pengumpulan data pemberian ASI dengan cara mengikuti semua bayi sejak lahir sampai umur 6 bulan. ${ }^{16}$

Data cakupan pemberian ASI eksklusif hasil Riskesdas, SDKI, dan laporan program ternyata berbeda. Hasil Riskesdas 2010 dan SDKI 2007 menunjukkan bahwa cakupan pemberian ASI eksklusif selama 6 bulan menurun, sedangkan pada laporan program cakupan indikator SPM cenderung meningkat. Perbedaan tersebut dapat terjadi karena perbedaan metode yang digunakan dalam pegumpulan data. ${ }^{16,17}$

Angka cakupan pemberian ASI eksklusif bayi 0-5 bulan sebesar 27,2 persen dan 15,3 persen pada kelompok bayi umur 5 bulan menurut Riskesdas 2010, masih terlalu rendah, karena target cakupan pemberian ASI eksklusif pada bayi kurang dari 6 bulan adalah 80 persen. Berdasarkan data Riskesdas 2010 dilakukan analisis lanjut terhadap variabel yang berkaitan dengan rendahnya cakupan pemberian ASI eksklusif, yaitu proses mulai menyusui, pemberian makanan prelakteal, dan umur bayi mulai diberi makanan atau minuman selain ASI. ${ }^{16}$

Data Riskesdas 2010 menunjukkan bahwa pada bayi umur 0-5 yang segera disusui setelah lahir $(<1$ jam) adalah 27,5 persen, dan yang diberi makanan atau minuman prelakteal ketika baru lahir adalah 44,7 persen dengan jenis makanan atau minuman yang diberikan sebagai makanan prelakteal 73,9 persen berupa susu formula. Persentase bayi umur 0-5 bulan yang mulai diberi makanan atau minuman selain ASI pada saat umur 0-7 hari sebesar 31,8 persen. Pada bayi yang mulai diberi makanan atau minuman selain ASI pada umur 0-7 hari 80,7 persen diberi susu formula dan 4,3 persen diberi pisang. Setelah dianalisis lebih lanjut bayi yang diberi makanan atau minuman pada saat umur 0-7 hari ternyata 84,2 persen pada saat lahir ditolong oleh tenaga kesehatan. ${ }^{16}$

Ada fenomena yang "menarik namun ironis" dalam rangkaian perawatan kesehatan bayi sejak lahir, yaitu: cakupan persalinan bayi umur 0-5 bulan yang ditolong oleh tenaga kesehatan tinggi $(84,7 \%)$ dan cenderung meningkat; berat bayi lahir rendah cenderung menurun dari 11,5 persen pada tahun 2007 menjadi 10,3 persen pada tahun 2010; kunjungan neonatus 0-48 jam cukup tinggi $(71,4 \%)$; tetapi bayi yang mulai disusui kurang dari 1 jam setelah lahir masih rendah $(29,3 \%)$; bayi yang diberi makanan atau minuman prelakteal masih tinggi $(43,6 \%)$; bayi umur $0-5$ bulan yang diberi makanan atau minuman selain ASI masih pada saat umur 0-7 hari masih tinggi $(31,8 \%)$, cakupan pemberian ASI eksklusif pada bayi umur 0-5 masih rendah bahkan menurun dari 40,0 persen pada tahun 2002 menjadi 32,0 persen pada tahun 2007 dan 27,2 persen pada tahun 2010; dan cakupan pemberian ASI eksklusif pada bayi umur 5 bulan masih rendah (15,3\%). ${ }^{16}$

Bagaimana bisa terjadi percepatan penurunan angka kematian bayi, jika salah satu rantai dalam rangkaian perawatan bayi yaitu menyusui bayi sesegera mungkin setelah lahir, dan memberikan ASI eksklusif sampai umur 6 bulan tidak banyak dilakukan? Hasil penelitian 
menunjukkan bahwa menyusui segera setelah lahir dapat meningkatkan keberhasilan pemberian ASI eksklusif, dan pemberian ASI eksklusif sampai umur 6 bulan dapat membantu menurunkan angka kesakitan dan kematian bayi khususnya neonatal antara 55-87 persen. ${ }^{18}$ Fasilitas dan tenaga kesehatan khususnya tenaga penolong persalinan sebenarnya mempunyai peranan yang sangat strategis dalam upaya meningkatkan cakupan pemberian ASI eksklusif sampai umur 6 bulan dan membantu mempercepat penurunan angka kematian bayi.

\section{SIMPULAN}

1. Akurasi data estimasi cakupan pemberian ASI eksklusif tergantung pada definisi, batasan umur, dan metode pengumpulan data yang digunakan. Data cakupan pemberian ASI eksklusif yang dikumpulkan dengan metode recall 24 jam selalu lebih tinggi daripada data aktual di populasi, karena waktu recall yang terlalu singkat dan selalu ada kemungkinan bayi yang telah diberi makanan selain ASI pada harihari sebelum hari recall.

2. Interpretasi data hasil survei dan laporan program perlu dilakukan secara hati-hati dan cermat, karena perbedaan definisi, batasan waktu dan metode yang digunakan dalam pengumpulan dan penyajian data akan memberikan implikasi yang berbeda terhadap strategi program peningkatan cakupan pemberian ASI eksklusif.

3. Data cakupan pemberian ASI eksklusif yang dikumpulkan dengan metode recall 24 jam perlu dikombinasi dengan recall sejak lahir serta dikontrol dengan pemberian makanan prelakteal, lebih akurat daripada hanya menggunakan metode recall 24 jam.

4. Data cakupan pemberian ASI eksklusif yang disajikan dalam bentuk rata-rata pada bayi yang berumur $0-5$ bulan, sebenarnya tidak merepresentasikan cakupan pemberian ASI eksklusif sampai umur 6 bulan di populasi. Kelompok bayi umur 5 bulan yang diberi ASI eksklusif lebih merepresentasikan cakupan pemberian ASI eksklusif sampai umur 6 bulan di populasi.

5. Metode yang paling tepat untuk mengukur cakupan pemberian ASI eksklusif sampai umur 6 bulan adalah dengan metode kohor, yaitu melakukan pengumpulan data pemberian ASI dengan cara mengikuti semua bayi sejak lahir sampai umur 6 bulan.

\section{REKOMENDASI}

1. Untuk meningkatkan akurasi data cakupan pemberian ASI eksklusif yang dikumpulkan melalui survei atau laporan program, metode recall 24 jam perlu dikombinasi dengan recall sejak lahir dan dikontrol dengan pemberian makanan atau minuman prelakteal.

2. Menyusui segera setelah lahir dapat meningkatkan keberhasilan pemberian ASI eksklusif, dan pemberian ASI eksklusif sampai umur 6 bulan dapat membantu menurunkan angka kesakitan dan kematian bayi. Fasilitas dan tenaga kesehatan khususnya tenaga penolong persalinan mempunyai peranan yang sangat strategis dalam upaya meningkatkan cakupan pemberian ASI eksklusif sampai umur 6 bulan. Oleh karena itu perlu adanya peraturan dan penerapan sanksi bagi semua fasilitas dan tenaga penolong persalinan yang tidak mendukung pemberian ASI eksklusif dan pemberian penghargaan bagi semua fasilitas dan tenaga penolong persalinan yang mendukung pemberian ASI eksklusif. Sanksi dan penghargaan dapat diberikan pada saat akreditasi, perijinan, dan kenaikan pangkat, khususnya bagi pegawai negeri sipil.

\section{RUJUKAN}

1. Eregie, C.O. 1997. Observations on Certain Factors Associated With Exclusive Breastfeeding. International Child Health: A Digest of Current Information. An International Pediatrics Association Publication in Collaboration with UNICEF and WHO. VIII, 3: 49-54.

2. Curthbertson, W.F.J. Review Article : Evolution of Infant Nutrition. Am J Clin Nutr, 1999, 81: 359-371.

3. Eregie, C.O. and Abraham, R. Studies on Exclusive Breastfeeding : Observations on 
the Adequacy of Breast Milk as Sole Nutrient for the First Six months of Life. International Child Health: A Digest of Current Information. An International Pediatrics Association Publication in Collaboration with UNICEF and WHO,1997, VIII, 4: 49-54.

4. World Health Organization. Global strategy for infant and young child feeding. WHA 55/2002/REC/l, annex 2. Geneva: World Health Organization.2002.

5. Popkin, B.M., Adair, L., VanDerslice, J., Akin, J., Guilkey, D., and Black, R. Breastfeeding and diarrheal morbidity. Pediatrics.1990, 86: 874-882.

6. Arifeen, S. et.al. Exclusive breastfeeding reduces acute respiratory infection and dearrhoea death among infant in Dhaka slum. Pediatrics.2001,108 (4):E67.

7. Chua, S., Arulkumaran, S., Lim, I., Selamat, N., and Ratnam, S.S. Influent of breastfeeding and nipple stimulation on postpartum uterine activity. $\mathrm{Br} \mathrm{J}$ Obstet Gynaecol,1994, 101:804-805.

8. Semega-Janneh, I.J. Breastfeeding : from Biology to Policy. Challenges for the $21^{\text {st }}$ Century : A Gender Perspective on Nutrition Through the Life Cycle. Paper from the ACC/SCN 25 th Session Symposium, Oslo, Norway, 30 March and 1 April, 1998. 82-94.

9. Kennedy, K.I., Labbok, M.H., and Van Look, P.F. Lactational amenorrhea method for family planning. Int J Gynaecol Obstet. 1996. 54:55-57.

10. Dewey, K.G., Heinig, M.J., and Nommsen, L.A. Maternal weight-loss patterns during prolonged lactation. Am J Clin Nutr. 1993, 58:162-166.
11. Newcomb, P.A., Storer, B.E. Longnecker, M.P., et.al. Lactation and reduced risk of premenopousal breast cancer. N Engl J Med.,1994, 330:81-87.

12. Rosenblatt, K.A. and Thomas, D.B. Lactation and the risk of epithelial ovarium cancer. WHO Collaborative Study of Neoplasia and Steroid Contraceptives. Int J Epidemiol. 1993,22:192-197

13. Piwoz, E.G., Creed de Kanashiro, H., Lopes de Romana, G., Black, R.E., Brown, K.H. Potential for misclassification of infants usual feeding practices using 24-hour dietary assessment methods. J Nutr. 1995, 125: 57-65.

14. Aarts, C., Kylberg, E., Hornell, A., Hofvander, Y., Gebre-Medhin, M.,Greiner, T. How exclusive is exclusive breastfeeding? A comparasion of data since birth with current status data. Int J Epidemiol, 2000, 29: 1041-1046.

15. Badan Pusat Statistik (BPS) dan Marco International. Survei Demografi dan Kesehatan Indonesia 2007. Calverton. Maryland, USA: BPS dan Marco International, 2007.

16. Badan Penelitian dan Pengembangan Kesehatan. Laporan Hasil Riset Kesehatan Dasar 2010. Jakarta: Kementerian Kesehatan, R.I. Jakarta, 2010.

17. Indikator Standar Pelayanan Minimal Bidang Kesehatan Kabupaten/Kota. Indikator SPM 2003-2007. http://www.spm.depkes.go.id/

18. Darmstadt, et al. Evidence based costeffective interventions: ow many newborn babies can we save? Neonatal Survival 2. The Lancet, 2005:19-30 